\title{
O drama da beleza na poesia de Sophia de Mello Breyner Andresen
}

The drama of beauty in the poetry of

Sophia de Mello Breyner Andresen

\section{Luis Adriano Carlos*}

Arquivo enviado em

$13 / 07 / 2019$

e aprovado em

24/07/2019.

V. $9-$ N. $18-2019$

*Doutor em Literatura

Portuguesa Moderna e Contemporânea e Professor Associado com Agregação da Faculdade de Letras da

Universidade do Porto. 


\section{Abstract}

When we celebrate the centenary of the birth of the Portuguese author (1919-2004), who won the Camões Prize in 1999 and whose body lies in the National Pantheon, in Lisbon, since 2014, a critical revisitation of her poetic work is still justified. She is the most prominent female figure in the gallery of Portuguese poets of the 20th century and is patroness of the Chair of Poetry and Transcendence of the Portuguese Catholic University, in Oporto, directed by José Rui Teixeira. Belonging to the important generation of "Cadernos de Poesia", with Jorge de Sena and other poets from the period of Second World War and Cold War, she produced a unique imagist poetics of Mediterranean clarity and Apollonian beauty. However, the present study seeks to show that Beauty in Sophia, usually associated with unstrained and solemn serenity, involves a dramatic and Dionysian character that introduces an element of vitality and transcendence, which forces a revision of its place in the history of aesthetic forms of contemporary Portuguese poetry.

Key Words: Literary Aesthetics; Artistic Beautiful; Beauty and Tragic; Apollonian and Dionysian; Poetry and Transcendence.

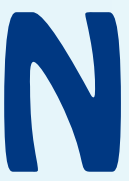

ão serei original se começar por dizer que Sophia de Mello Breyner Andresen (1919-2004) procura a essência da beleza em todos os quadrantes da sua poesia. Talvez nenhum outro autor moderno das Letras portuguesas tenha exercitado essa demanda com tanta persistência e de forma tão peculiar. A sua genuína filocalia seria trivial numa época de classicismo literário, mas acaba por se revestir de uma estranha singularidade na era dos modernismos, que amaldiçoou as estéticas do belo para consagrar o feio, o trágico, o horrível e o sublime.

Sucede que a proverbial beleza mediterrânica desta poesia, ainda que profundamente enraizada na cultura helénica que modelizou todos os tipos de classicismo artístico, está longe de ser uma beleza impassível, paliativa ou anémica. A autora pertence a uma geração que no início da década de 1940 enfrentava o impacto do Nazismo e que não tardaria a conhecer o horror do Holocausto e de Hiroshima. A experiência do terror faz parte 
da colecção de temas da sua geração literária, reunida em torno dos Cadernos de Poesia (1940-1953) e integrando poetas como Ruy Cinatti, José Blanc de Portugal, Tomaz Kim e Jorge de Sena. Por esse motivo, a pulcritude que habita o seu imaginário poético não se confina à ideia de unidade em eterno repouso com que se representa a beleza nos manuais de Estética e nas concepções convencionais.

Do ponto de vista da história da literatura e da cultura, Sophia Andresen integra a tradição romântica e prometaica em que o Homem se concebe a si mesmo como autor demiúrgico e criador original. A beleza, exilada do mundo clássico, já não é entendida como reflexo da verdade arquetípica — mas, pelo contrário, como produção de uma verdade incoativa e originária. A ironia romântica de John Keats no final de "Ode on a Grecian Urn" é todo um programa de crítica da forma ática: "A beleza é a verdade, a verdade a beleza, - isso é tudo / O que na terra sabeis, e tudo o que precisais de saber". Com a estética kantiana no seu subsolo, pulverizando a ontologia do belo, o Romantismo promoveu de facto uma ideia da beleza como criação autónoma, transfigurada por Charles Baudelaire na beleza infernal e divina de "Hymne à la Beauté". Para me servir de duas conhecidas metáforas de M. H. Abrams, o espelho da beleza converteu-se numa lâmpada com luz própria. A beleza clássica teria contudo as suas possibilidades, como forma do estranho e do dissonante, num quadro conceptual em que as suas manifestações se tornaram raras e, ironicamente, marginais. É, em primeira análise, o caso da poesia andresiana.

A dissonância verifica-se desde logo nas causas primeiras do assunto que me proponho abordar: sendo a autora um produto romântico, como todos os modernistas históricos, a sua obra poética 
mergulha as raízes estéticas na arte clássica da Antiguidade grega, para a qual a beleza não é um drama, mas justamente o seu contrário, uma ordem estável e eterna. De resto, foi exactamente o drama, representado pela poesia mimética, que o maior teórico da beleza expulsou da cidade ideal, na República, em nome do to kalon como expressão do bem e da verdade. Com efeito, a autora de O Nu na Antiguidade Clássica não esconde o seu fascínio teórico pelo modo ordenado da representação artística: "o artista grego tenta mostrar a relação do homem com uma ordem que é a íntima estrutura do 'kosmos"'1. Nos seus próprios termos, o kosmos é um "mundo ordenado-belo", reproduzindo uma ideia de "ordem, beleza, serenidade, justiça"2. Acrescente-se que o kosmos dos gregos significa "ordem bela" e tem origem na metafísica matemática dos pitagóricos, segundo a qual a beleza deriva da perfeição da estrutura e da proporção das partes. A ordem do kosmos corresponde a uma estrutura harmónica, regida pelo princípio ordenador da simetria, que será imitada pela obra artística, síntese e universo de formas analógicas que promove uma Natureza Ideal coextensiva ao Belo Ideal.

Livro Sexto oferece-nos uma imagem singela desta concepção analógica do processo criador, num pequeno texto sugestivamente intitulado "No Poema", onde o trabalho poético é concebido como pura transposição e o poeta é um simples transferidor:

\footnotetext{
Transferir o quadro o muro a brisa

A flor o copo o brilho da madeira

$E$ a fria e virgem liquidez da água

Para o mundo do poema limpo e rigoroso

Preservar de decadência morte e ruína
}

1. Sophia de Mello Breyner Andresen, O Nu na Antiguidade Clássica, Lisboa: Portugália, 1975, pp. 5 e 6.

2. Idem, pp. 5 e 68. 
O instante real de aparição e de surpresa

Guardar num mundo claro

O gesto claro da mão tocando a mesa ${ }^{3}$

Entronca aqui a concepção da poesia como "explicação com o universo" que a autora expõe em "Arte Poética — II", epílogo do livro Geografia:

[...] a poesia é a minha explicação com o universo, a minha convivência com as coisas, a minha participação no real, o meu encontro com as vozes e as imagens. [...] É esta relação com o universo que define o poema como poema, como obra de criação poética. ${ }^{4}$

Nesta perspectiva, a autora chega a evocar - em "Arte Poética V", com que encerra o livro Ilhas - um sentimento pessoal do poema como mundo objectivo e imanente, ou mesmo como emanação cósmica, independente do sujeito criador:

Eu era de facto tão nova que nem sabia que os poemas eram escritos por pessoas, mas julgava que eram consubstanciais ao universo, que eram a respiração das coisas, o nome deste mundo dito por ele próprio.

Pensava também que, se conseguisse ficar completamente imóvel e muda em certos lugares mágicos do jardim, eu conseguiria ouvir um desses poemas que o próprio ar continha em si.

No fundo, toda a minha vida tentei escrever esse poema imanente. $E$ aqueles momentos de silêncio no fundo do jardim ensinaram-me, muito tempo mais tarde, que não há poesia em silêncio, sem que se tenha criado o vazio e a despersonalização.

Um dia em Epidauro - aproveitando o sossego deixado pelo horário do almoço dos turistas - coloquei-me no centro do teatro e disse em voz alta o princípio de um poema. E ouvi, no instante seguinte, lá no alto, a minha própria voz, livre, desligada de mim. ${ }^{5}$

Esta narrativa metaliterária do poema como kosmos reproduz uma outra já antes articulada em "Arte Poética IV", de Dual, sob os

3. Sophia de Mello Breyner Andresen, Obra Poética II, Lisboa: Caminho, 1991, p. 116.

4. Sophia de Mello Breyner Andresen, Obra Poética III, Lisboa: Caminho, 1991, p. 95.

5. Idem, p. 349. 
auspícios do mestre da despersonalização:

Fernando Pessoa dizia: "Aconteceu-me um poema." A minha maneira de escrever fundamental é muito próxima deste "acontecer". O poema aparece feito, emerge, dado (ou como se fosse dado). Como um ditado que escuto e noto.

É possível que esta maneira esteja em parte ligada ao facto de, na minha infância, muito antes de eu saber ler, me terem ensinado a decorar poemas. Encontrei a poesia antes de saber que havia literatura. Pensava que os poemas não eram escritos por ninguém, que existiam em si mesmos, por si mesmos, que eram como que um elemento do natural, que estavam suspensos, imanentes. E que bastaria estar muito quieta, calada e atenta para os ouvir. ${ }^{6}$

Em ambas as narrativas, o poema é pura estesia fenoménica, sem a dimensão eidética que se pressupõe na objectividade clássica. Porém, trata-se, em todo o caso, de uma intuição do ser em que a ordem artística se confunde harmoniosamente com a ordem cósmica. O poema é uma coisa que agrada ou encanta porque repercute a unidade da ordem do universo. Nesse sentido, o seu ser participa da concepção de beleza que será difundida pela tradição do classicismo literário, desde Platão e Aristóteles até Nicolas Boileau. A beleza como unidade na variedade - o to kalon -, legitimada na cultura ocidental por pensadores tão diversos como, por exemplo, Horácio, Santo Agostinho, S. Tomás de Aquino, Leon Battista Alberti, G. W. Leibniz, Jean-Pierre de Crousaz, Francis Hutcheson, Denis Diderot ou William Hogarth, entrou em profunda crise nos primórdios da Modernidade romântica, mas Sophia soube preservá-la com olímpica tenacidade, quase que a título de enteléquia do poema, contra todos os riscos estéticos que eram próprios do seu tempo.

Quando nasceu a Estética, por meados do século XVIII, era 6. Idem, p. 166. 
ainda a beleza clássica, de mãos dadas com a ideia de perfeição, que ocupava o centro do conhecimento sensível. Durante dois milénios, arte e beleza foram conceitos assimiláveis e muitas vezes sinónimos, mas esse monismo estético, conservado por A. G. Baumgarten ao erigir a nova jurisdição epistemológica, acabou por se cindir no dualismo belo-sublime, na segunda metade do século, através de Edmund Burke e Immanuel Kant. Com o Romantismo, o belo passou a integrar um sistema pluralista de categorias estéticas entre as quais se foi diluindo progressivamente. $\mathrm{O}$ feio, até então proscrito, desde a República de Platão, regressou triunfalmente à cidade, a par do grotesco e do sublime, do pitoresco e do trágico ou do burlesco e do cómico, para só mencionar as categorias mais relevantes. É sobre este fundo turvo e obscuro que se destaca a proverbial claridade da poesia de Sophia Andresen, celebrando desde o livro inaugural "A perfeição, a pureza e a harmonia"7. Todos os tópicos da beleza clássica (perfeição, eternidade, plenitude, luz, divindade, pureza, verdade, harmonia, absoluto) estão inscritos de forma sintética e ecfrástica na ode "Alexandre da Macedónia", de Dia do Mar.

A perfeição, a eternidade, a plenitude Escorriam da sagrada juventude Dos teus membros.

A luz bailava em roda dos teus passos

$\mathrm{E}$ a ardente palidez da tua divindade

Ergueu-se na pureza dos espaços.

Estreitamente os teus dedos

Para lá das vagas ânsias, incertezas e segredos

Prendiam os dedos da sorte.

E o destino que em nós é caos e luto,

Era em ti verdade e harmonia

Caminho puro e absoluto. ${ }^{8}$

7. Sophia de Mello Breyner Andresen, Obra Poética I, Lisboa: Caminho, 1991, p. 30.

8. Idem, p. 101. 
Entretanto, é forçoso reconhecer que a poesia da autora transcende os limites estéticos que acabo de desenhar. E digo que transcende porque de facto existe um eixo de transcendência na sua poesia que excede a mera referencialidade temática. Numa palavra, os seus versos provam que a estética moderna não renunciou ao sagrado, apesar de a história do gosto, desde o século XVIII, se narrar, pela pena dos mais credenciados especialistas, entre os quais Luc Ferry, como "emergência de um universo laico" em época marcada pela "predição de Nietzsche" segundo a qual "a verdade da obra de arte se encontra no artista, já não na natureza ou na divindade"9. Apesar disso, no universo poético de Sophia Andresen, a beleza é um interruptor entre o Homem e o Absoluto, que liga e desliga a corrente de comunicação ao sabor das flutuações tímicas e éticas da escrita. É esse plano da obra que explica a sua evolução de uma estética da proporção para uma estética da luz, sem que o imaginário se afaste da Grécia como referencial simbólico.

Ora, as estéticas da luz são habitualmente associadas ao Neoplatonismo, a começar na teoria fundamental de Plotino, que no seu tratado sobre o belo (Enéadas, I, 6) refuta convincentemente a teoria da proporção, mas a verdade é que também a concepção da beleza como esplendor nasce na obra de Platão. Na realidade, este filósofo perfilha as duas grandes concepções clássicas, a da beleza como harmonia e proporção das partes, de raiz pitagórica, e a da beleza como esplendor. Inclusive, no diálogo onde expõe a teoria da beleza como esplendor, o Fedro, propugna a concepção orgânica do discurso retórico como harmonia das partes

9. Luc Ferry, Le Sens du Beau: Aux Origines de la Culture Contemporaine, Paris: Librairie Générale Française, 2002, pp. 16 e 20. 
e do todo ${ }^{10}$. O que, de qualquer modo, é submerso pela concepção da beleza eidética como "luminosidade pura e deslumbrante" que "ofusca todas as coisas com o seu brilho"11. A ideia de beleza como emanação, tradicionalmente creditada ao Neoplatonismo, é outrossim uma ideia platónica, ainda que com diferenças específicas: quando se contempla o objecto amado como se fosse um deus - assevera Sócrates - recebe-se "a emanação da beleza" pelos olhos, através dos quais ela se reflecte, atingindo a alma ${ }^{12}$. O belo é o esplendor metafísico da Ideia, do bem e da verdade.

Um neoplatónico francês do século XIX, o Padre Charles Clair, no tratado Le Beau et les Beaux-Arts, de 1882, testemunha a actualidade teórica do belo como esplendor, indiferente à marcha da Estética, que aniquilara a ontologia da beleza com Kant e o Romantismo. Para o autor, são errados os sistemas de explicação que associam o belo ao útil e ao agradável, à novidade e ao hábito, à grandeza e ao exagero, à imitação e à ilusão ${ }^{13}$. Por outro lado, são sistemas incompletos, no seu entender, aqueles que repousam sobre os critérios da ordem, da proporção, da unidade e da variedade, meras condições da beleza que não constituem por si sós a sua essência ${ }^{14}$. Charles Clair reconhece que a unidade é a forma e essência do belo desde Santo Agostinho, porém alega que, sendo a unidade e a variedade condições do belo, não são contudo os seus princípios ${ }^{15}$. Argumento que deve ser entendido no contexto das teorias de Plotino e S. Tomás, graças às quais o autor considera que o belo em si mesmo e no seu princípio é "o es-

10. Platão, Fedro, Lisboa: Guimarães Editores, 1981, p. 119.

11. Idem, p. 79.

12. Idem, pp. 81 e 91.

13. Charles Clair, Le Beau et les Beaux-Arts, Paris: Librairie H. Oudin, 1882, 3-10.

14. Idem, pp. 10 a 13.

15. Idem, p. 12. 
plendor do verdadeiro e do bem", "a irradiação, o reflexo de Deus no espelho das coisas sensíveis" ${ }^{\prime 16}$.

Este reflexo de Deus é perceptível em vários poemas de Sophia Andresen, por vezes estruturados como invocações ou preces, que em conjunto sugerem o emblema moral da beleza como esplendor que a Renascença italiana conheceu na Iconologia de Cesare Ripa. No poema "Se todo o Ser", do livro de estreia, Poesia $I$, divisamos o esplendor plotiniano reflectido na alma, ou terceira hipóstase, que estabelece a comunicação entre o sensível e o inteligível, recebendo a emanação da Forma e do Bem:

Quando a manhã brilhar refloriremos

E a alma beberá esse esplendor

Prometido nas formas que perdemos ${ }^{17}$

O desejo de ascensão até ao Uno, ou primeira hipóstase, que é o Bem e o princípio da Beleza inteligível, vem sugerido na composição que se segue, "As Fontes":

\footnotetext{
Um dia quebrarei todas as pontes

Que ligam o meu ser, vivo e total,

À agitação do mundo do irreal,

$E$ calma subirei até às fontes.

Irei até às fontes onde mora

A plenitude, o límpido esplendor

Que me foi prometido em cada hora,

E na face incompleta do amor.

Irei beber a luz e o amanhecer,

Irei beber a voz dessa promessa

Que às vezes como um voo me atravessa,

E nela cumprirei todo o meu ser. ${ }^{18}$
}

No poema em prosa "As Grutas", de Livro Sexto, assistimos à narrativa da criação como emanação e esplendor:

16. Idem, p. 17.

17. Sophia de Mello Breyner Andresen, Obra Poética I, Ob. cit., p. 59.

18. Idem, p. 60. 
O esplendor poisava solene sobre o mar. E - entre as duas pedras erguidas numa relação tão justa que é talvez ali o lugar da Balança onde o equilíbrio do homem com as coisas é medido - quase me cega a perfeição como um sol olhando de frente. Mas logo as águas verdes em sua transparência me diluem e eu mergulho tocando o silêncio azul e rápido dos peixes. Porém a beleza não é solene mas também inumerável. De forma em forma vejo o mundo nascer e ser criado. ${ }^{19}$

A mesma ideia demiúrgica e emanativa é representada em verso imediatamente a seguir, no bem conhecido poema "Ressurgiremos" que evoca Delfos como "centro do mundo" e Creta como fonte da luz:

Ressurgiremos ainda sob os muros de Cnossos
E em Delphos centro do mundo
Ressurgiremos ainda na dura luz de Creta
Ressurgiremos ali onde as palavras
São o nome das coisas
E onde são claros e vivos os contornos
Na aguda luz de Creta
Ressurgiremos ali onde pedra estrela e tempo
São o reino do homem
Ressurgiremos para olhar para a terra de frente
Na luz limpa de Creta
Pois convém tornar claro o coração do homem
E erguer a negra exactidão da cruz
Na luz branca de Creta ${ }^{20}$

Todavia, há que não cair na ilusão do esplendor neoplatónico como telos da poesia da autora, porquanto ela é essencialmente dual, para utilizar a palavra que deu título ao livro de 1972. O esplendor é nela não apenas metafísico, mas também fenoménico. A perfeição das Formas participa de um jogo de dualidades em que o imperfeito e o kaos disputam a preponderância. Teremos, por conseguinte, de recuar para além da "idade dos filósofos", até

19. Sophia de Mello Breyner Andresen, Obra Poética II, Ob. cit., p. 107.

20. Idem, p. 109. 
à "idade dos heróis", usando a terminologia de Giambattista Vico, para descobrirmos a origem do esplendor andresiano: "Em Homero reconheci essa felicidade nua e inteira, esse esplendor da presença das coisas", confessa a autora no discurso com que recebeu o Grande Prémio de Poesia da Sociedade Portuguesa de Escritores, em 1964, e que se destinaria a prefácio da Obra Poética ${ }^{21}$. O belo é aqui um belo natural, designativo e concreto, texturado, fruto da experiência do mundo e síntese da ordem épica dos acontecimentos, como se depreende da continuação do discurso:

Sempre a poesia foi para mim uma perseguição do real. Um poema foi sempre um círculo traçado à roda duma coisa, um círculo onde o pássaro do real fica preso. E se a minha poesia, tendo partido do ar, do mar e da luz, evoluiu, evoluiu sempre dentro dessa busca atenta. Quem procura uma relação justa com a pedra, com a árvore, com o rio, é necessariamente levado, pelo espírito de verdade que o anima, a procurar uma relação justa com o homem. Aquele que vê o espantoso esplendor do mundo é logicamente levado a ver o espantoso sofrimento do mundo. Aquele que vê o fenómeno quer ver todo o fenómeno. ${ }^{22}$

O "espantoso esplendor do mundo" é uma luz sublime que, no entanto, não pode ofuscar o "espantoso sofrimento do mundo" numa consciência poética animada pelo humanismo cristão. Por isso a demanda da beleza na poesia andresiana desce amiúde do Uno para o múltiplo e para a alteridade da matéria, enfrentando o trágico e o feio. Nesses casos, o poema procura o invisível do visível, "O que há de aparição no seio da aparência", sob a égide do transcendentalismo panteísta de Teixeira de Pascoaes, como sugere a autora a propósito da pintura de Maria Helena Vieira da

21. Sophia de Mello Breyner Andresen, Obra Poética I, Ob. cit., p. 7.

22. Ibidem. 
Silva $^{23}$. Aqui a transcendência das coisas é a sua imanência mais recôndita, a que só uma fenomenologia descritiva poderá aceder. Daí que o conhecimento dos fenómenos, em toda a extensão das metáforas e alegorias em desfile, desencadeie uma poética dos elementos e da intimidade da matéria inspirada nos pré-socráticos e na lição entre biológica e teológica do Padre Teilhard de Chardin, que a autora cita electivamente no final do mesmo prefácio para sublinhar "a nossa confiança no progresso das coisas" 24 . A obra Le Phénomène Humain, de 1955, ensina-nos de facto que "as coisas têm o seu interior", coextensivo ao seu exterior, e que a "flecha da evolução" corresponde a uma "ascensão para a consciência"25.

O mundo sofre espantosamente - eis o juízo estético possível neste ângulo da obra da autora. A atenção aos fenómenos e a pesquisa poética da sua imanência salva esta poesia tão aristocrática do esteticismo autotélico que caracterizou a Modernidade baudelairiana, reconciliando a beleza com o to kalon, conceito simultaneamente estético e moral esvaziado de conteúdo ontológico pelo Romantismo e por todos os tipos de Modernismo. Sophia Andresen desce da sua torre de marfim, como se dizia na sua época, para reinvestir o belo de uma dimensão moral comprometida com a expressão da verdade. Ainda no mesmo prefácio, a autora conclui:

E é por isso que a poesia é uma moral. E é por isso que o poeta é levado a buscar a justiça pela própria natureza da sua poesia. E a busca da justiça é desde sempre uma coordenada fundamental de toda a obra poética. Vemos que no teatro grego o tema da justiça é a própria respiração das palavras. ${ }^{26}$

23. Sophia de Mello Breyner Andresen, Obra Poética III, Ob. cit., p. 341.

24. Sophia de Mello Breyner Andresen, Obra Poética I, Ob. cit., p. 9.

25. Teilhard de Chardin, O Fenómeno Humano, Apelação: Paulus, 1998, pp. 18, 35-38, 126, 131 e 243.

26. Sophia de Mello Breyner Andresen, Obra Poética I, Ob. cit., p. 7. 
Tal como na República de Platão, esta forma de justiça confunde-se ainda com uma ideia de simetria. Sem embargo, trata-se de um "equilíbrio das coisas" que governa "aquela ordem do mundo onde o poeta quer integrar o seu canto", já não apenas como "alegria" perante o "esplendor do mundo" mas sobretudo como "revolta" perante o "sofrimento do mundo" 27 . A poesia é simultaneamente ode e sátira, funções que sempre desempenhou enquanto fenómeno humano, ora em conflito, ora em coligação. "O facto de sermos feitos de louvor e protesto - salienta ainda a autora - testemunha a unidade da nossa consciência"28. Uma unidade que, desligada da "beleza em si", se transfere para o seu fenómeno enquanto manifestação significante, conforme se infere de uma passagem de "Arte Poética — l":

A beleza da ânfora de barro pálido é tão evidente, tão certa que não pode ser descrita. Mas eu sei que a palavra beleza não é nada, sei que a beleza não existe em si mas é apenas o rosto, a forma, o sinal de uma verdade da qual ela não pode ser separada. Não falo de uma beleza estética mas sim de uma beleza poética. ${ }^{29}$

Não obstante, a beleza é muitas vezes separada da verdade, com a qual mantém uma relação semiótica, e nessa medida vive o mesmo drama da linguagem. Ela é um pharmakon, um remédio e um veneno que consola e que mata, mas também um mero cosmético que retira dignidade moral à arte e à poesia. Por esse motivo, na óptica da responsabilidade do artista de que falava Jacques Maritain num influente ensaio de $1961^{30}$, só é pensável como beleza dramática, tensa e em sofrimento, lugar do pathos e da discórdia, sede da dualidade e da fractura. Já não é a harmonia do

27. Idem, p. 8.

28. Ibidem.

29. Sophia de Mello Breyner Andresen, Obra Poética III, Ob. cit., p. 93.

30. Jacques Maritain, La Responsabilité de l'Artiste, Paris: Arthème Fayard, 1961. 
kosmos que o poema imita: é o kaos nas suas desarmonias, como que saído das Purificações de Empédocles, onde a cosmogonia emerge do atrito e do conflito entre o Amor e a Discórdia.

Este regresso à velha e relha questão da verdade na poesia vem inteiramente desalinhado da mentira mimética de Platão e do verosímil ficcional de Aristóteles. Ainda no mesmo prefácio: "Há um desejo de rigor e de verdade que é intrínseco à íntima estrutura do poema e que não pode aceitar uma ordem falsa" ${ }^{31}$. Estamos perante a inscrição do tema na ordem do "tempo dividido", literalmente ao nível mais atómico da matéria, e portanto no cerne de uma história literária que foi a dos anos da II Grande Guerra e do pós-guerra, condicionada pela problemática da responsabilidade do artista e do engagement, quer na área neo-realista, quer no campo dos existencialismos onde se destacaram as teorias do testemunho, sobretudo através de Gabriel Marcel e Jean-Paul Sartre, que teriam repercussões directas num influente prefácio de Jorge de Sena, um dos poetas mais próximos de Sophia Andresen ${ }^{32}$. Quanto ao mais, a autora utiliza uma linguagem que não é senão a anamnese do polemismo entre presencistas (poetas da revista Presença criada em 1927) e neo-realistas ocorrido por volta de 1940, em torno do entendimento da finalidade artística, adoptando uma postura crítica em relação à tese dos valores autónomos do belo, do verdadeiro e do justo consagrada pela obra de Julien Benda então em voga, La Trahison des Clercs:

O artista não é, e nunca foi, um homem isolado que vive no alto duma torre de marfim. O artista, mesmo aquele que mais se coloca à margem da convivência, influenciará necessariamente, através da sua obra, a vida e o destino dos outros. Mesmo que o artista escolha o iso-

31. Sophia de Mello Breyner Andresen, Obra Poética I, Ob. Cit., p. 8.

32. Cf. Jorge de Sena, Prefácio a Poesia-I, Lisboa: Livraria Morais, 1961. 
lamento como melhor condição de trabalho e criação, pelo simples facto de fazer uma obra de rigor, de verdade e de consciência ele irá contribuir para a formação duma consciência comum. Mesmo que ele fale somente de pedras ou de brisas a obra do artista vem sempre dizer-nos isto: que não somos apenas animais acossados na luta pela sobrevivência mas que somos, por direito natural, herdeiros da liberdade e da dignidade do ser. ${ }^{33}$

A atitude empenhada face ao homem em situação provoca a transmutação da estética da luz numa estética saturniana, em que a consciência infeliz alimenta um ethos melancólico cuja melhor síntese nos aparece em "P'ra Minha Imperfeição", de Dia do Mar.

P'ra minha imperfeição está suspenso

Em cada flor da terra um tédio imenso.

Todo o milagre, toda a maravilha

Torna mais funda a minha solidão.

E todo o esplendor pra mim é vão,

Pois não sou perfeição nem maravilha.

As flores, as manhãs, o vento, o mar

Não podem embalar a minha vida.

Imperfeita não posso comungar

Na perfeição aos deuses oferecida. ${ }^{34}$

A voz poética representa-se agora como órfã dos deuses devorada pela usura do Tempo, exactamente no poema epónimo "No Tempo Dividido":

E agora ó Deuses que vos direi de mim?

Tardes inertes morrem no jardim.

Esqueci-me de vós e sem memória

Caminho nos caminhos onde o tempo

Como um monstro a si próprio se devora. ${ }^{35}$

O Tempo é o mundo imundo, a violência contra a forma, o kaos e a amorfia, tal como se representa sinteticamente nos poemetos "Cidade" e "Cidade Suja", de Poesia I: "Cidade, rumor e vaivém

33. Sophia de Mello Breyner Andresen, Obra Poética I, Ob. cit., p. 8.

34. Idem, p. 149.

35. Sophia de Mello Breyner Andresen, Obra Poética II, Ob. cit., p. 34. 
sem paz das ruas / ó vida suja, hostil, inutilmente gasta"36. Neste extremo da dualidade, a beleza é por momentos o seu próprio contraditório, o feio, exprimindo-se como negatividade e multiplicidade, à imagem e semelhança do poemeto "Terror de te Amar", de Coral:

Terror de te amar num sítio tão frágil como o mundo.

Mal de te amar neste lugar de imperfeição

Onde tudo nos quebra e emudece

Onde tudo nos mente e nos separa ${ }^{37}$

Ainda neste livro, o sentimento agónico da desordem é poeticamente expresso nos versos de "Numa Disciplina":

Numa disciplina constante procuro a lei da liberdade medindo o equilíbrio dos meus passos.

Mas as coisas têm máscaras e véus com que me enganam, e, quando eu um momento espantada me esqueço, força perversa das coisas ata-me os braços e atira-me, prisioneira de ninguém mas só de laços, para o vazio horror das voltas do caminho. ${ }^{38}$

O Mal sofrido de quem se perdeu "na sordidez do mundo"39 e a infigurabilidade de Deus justificam por fim um poema teodiceico na prece "Senhor", de Mar Novo:

Senhor se da tua pura justiça

Nascem os monstros que em minha roda eu vejo

É porque alguém te venceu ou desviou

Em não sei que penumbra os teus caminhos

Foram talvez os anjos revoltados. Muito tempo antes de eu ter vindo Já se tinha a tua obra dividido

E em vão eu busco a tua face antiga

És sempre um deus que nunca tem um rosto

Por muito que eu te chame e te persiga. ${ }^{40}$

36. Sophia de Mello Breyner Andresen, Obra Poética I, Ob. cit., pp. 27 e 29.

37. Idem, p. 178.

38. Idem, p. 170.

39. Sophia de Mello Breyner Andresen, Obra Poética III, Ob. cit., p. 21.

40. Sophia de Mello Breyner Andresen, Obra Poética II, Ob. cit., p. 47. 
Face a toda esta pluralidade, importa focar o princípio de estrutura que organiza a obra como sistema. Trata-se ainda de um princípio procedente da matriz grega, mas com o contributo inevitável e fundamental de um filósofo antiplatónico, Friedrich Nietzsche, aspecto já estudado pela crítica andresiana.

No ensaio O Nu na Antiguidade Clássica, a autora destaca o valor primordial da dualidade contraditória nestes termos:

Pois o mundo grego nunca é o mundo da pura serenidade apolínea. O espírito apolíneo aparece sempre conjugado com a força dionisíaca. E o Kaos, anterior a tudo, assedia o Kosmos. A claridade grega é uma claridade que reconhece a treva e a enfrenta. [...] O dual, o princípio da dualidade criadora, preside a toda a arte grega: Kaos e Kosmos, Apolo e Dionísio [...]. ${ }^{41}$

Apesar disso, a percepção geral da poesia da autora, que prevalece na sua imagem escolar e académica, atribuindo-lhe predicados como a serenidade e a claridade, consiste numa redução apolínea derivada de uma sensibilidade neoclássica muito própria dos paradigmas institucionais. Talvez o poema "Apolo Musageta" seja uma das causas dessa redução, na medida em que sintetiza os tópicos principais do cânone clássico, tal como foram estabelecidos por Policleto e Platão:

\footnotetext{
Eras o primeiro dia inteiro e puro

Banhando os horizontes de louvor.

Eras o espírito a falar em cada linha

Eras a madrugada em flor

Entre a brisa marinha.

Eras uma vela bebendo o vento dos espaços

Eras o gesto luminoso de dois braços

Abertos sem limite.

Eras a pureza e a força do mar

Eras o conhecimento pelo amor.
}

41. Sophia de Mello Breyner Andresen, O Nu na Antiguidade Clássica, Ob. cit., pp. 14 e 23. 
Sonho e presença

de uma vida florindo

Possuída e suspensa.

Eras a medida suprema, o cânon eterno

Erguido puro, perfeito e harmonioso

No coração da vida e para além da vida

No coração dos ritmos secretos. ${ }^{42}$

Apolo é o deus de quase todos os valores positivos que informam a estética andresiana: forma, luz, pureza, perfeição, harmonia, equilíbrio, beleza. Além disso, Apolo Musageta conduz as musas, é o portador da lira e o deus da poesia. Porém, ao longo da obra, esta figura mitológica é sistematicamente apresentada em contraponto com Diónisos, deus da "consciência múltipla e divina"43 nos termos do dístico que antecede a ode "Apolo Musageta". Esta polaridade é intrinsecamente dualística por exercer a mediação do elemento dionisíaco que transforma a beleza num drama estético, condensado nos versos lapidares da composição "O Efebo", de Dual:

Claro e esguiamente medido como a amphora Como a amphora

Ele contém um vinho intenso e resinado

A lucidez da sua forma oculta a embriaguez

A sua claridade conduz-nos ao encontro da noite

A sua rectidão de coluna preside à imanência dos desastres ${ }^{44}$

Contra os preceitos da estética clássica que recomendavam a obediência à razão suficiente e ao princípio da não-contradição, a poesia da autora estrutura-se precisamente como conflito antinómico e irredutível a uma solução harmoniosa, na esteira do que preconizava Friedrich Nietzsche em Die Geburt der Tragödie aus dem Geiste der Musik, de 1872. Não se trata de harmonizar os espíritos apolíneo e dionisíaco, dois tipos artísticos separados pela

42. Sophia de Mello Breyner Andresen, Obra Poética I, Ob. cit., p. 23.

43. Idem, p. 22.

44. Sophia de Mello Breyner Andresen, Obra Poética III, Ob. cit., p. 152. 
antítese e que manifestam, respectivamente, o "desejo de beleza" e o "princípio da individuação", por um lado, e o "desejo do horrível", a quebra do "jugo da individuação" e a libertação da verdade, por outro. Pelo contrário, trata-se de ambicionar a realização da "obra superior", que para o filósofo germânico seria "ao mesmo tempo apolínea e dionisíaca", despertando o "génio dionisíaco-apolíneo" como síntese suprema de dois impulsos artísticos que podem concorrer "paralelamente para uma acção comum"45. Se a ambição foi consumada, é um enigma a que só a apreciação estética desse supremo magistrado do gosto que é o Tempo poderá responder, mas parece evidente que o dualismo dinâmico destes dois impulsos na obra poética da autora lhe confere um tónus e uma profundidade dificilmente alcançáveis por uma solução monista em qualquer dos sentidos antitéticos.

Assim sendo, enfrentamos agora a questão de saber se o drama da beleza ainda nos mantém dentro dos limites do belo. O que sabemos, liminarmente, é que o belo começou por ser um conceito puro do entendimento, independente da experiência, com Platão e o Neoplatonismo, e acabou por se tornar uma simples representação, sem conceito e desinteressada, mera vivência empírica de um comprazimento subjectivo, com a crítica estética de Kant. Também sabemos, por isso mesmo, não ser abolutamente certo que o belo corresponda apenas a um juízo reflexivo sem conceito, uma vez que a sua história milenar demonstra à saciedade que, bem ou mal, tem conceito. Dir-se-ia até que tem conceito a mais, tantas são as teorias e doutrinas que dele se ocupam, e que a sua realidade pode ser inteiramente livre da experiência. Portanto, tratar-se-á de um conceito puro do entendimento, de uma coisa

45. Friedrich Nietzsche, A Origem da Tragédia, Lisboa: Guimarães Editores, 1982, pp. $35,53,117,119$ e 123. 
em si, ou, em alternativa, de uma pura intuição da sensibilidade fundada na experiência, um mero fenómeno?

Na teoria estética, o belo é entendido como categoria a priori, na medida da sua universalidade transcendental, em oposição ao estilo, que se reveste de um carácter histórico e particular. Ao contrário de conceitos histórico-estilísticos como "clássico", "barroco" ou "romântico", a categoria estética não carece de explicação ou conhecimento nem é passível de decomposição analítica ${ }^{46}$. Nessa perspectiva, o belo seria reciprocamente uma pura intuição, sem mediação de conceitos, que qualquer sujeito pode experimentar sem necessidade de determinação conceptual. De resto, a beleza como sensação faz parte da experiência comum, em que mesmo uma criança de tenra idade produz juízos estéticos de comprazimento. E é proverbial que "quem o feio ama, belo lhe parece", independentemente de qualquer objectividade. Estamos, neste ponto, muito próximos do belo kantiano, que se refere estritamente ao estado do sujeito.

Não obstante, é igualmente verdade que, quando afirmamos, por exemplo, que o sublime não é o belo - como fez Edmund Burke em 1757, ao refutar o estatuto de "superlativo do belo" conferido pela tradição clássica ao termo longiniano ${ }^{47}$ —, estamos a pressupor a existência de conceitos explicativos. Ademais, a conceptualização do belo por platónicos, neoplatónicos e cartesianos é passível de decomposição analítica e a sua compreensão requer conhecimentos que transcendem a mera intuição: o belo enquanto

46. Cf. Robert Blanché, Des Catégories Esthétiques, Paris: Vrin, 1979, pp. 116 ss.; e Étienne Souriau, Les Catégories Esthétiques, Paris: Centre de Documentation Universitaire, 1966, pp. 76 ss.

47. Cf. Edmund Burke, A Philosophical Enquiry into the Origin of Our Ideas of the Sublime and Beautiful, Nova lorque: Oxford University Press, 1998; e Baldine Saint Girons, Fiat Lux: Une Philosophie du Sublime, Paris: Quai Voltaire, 1993. 
conceito decompõe-se em propriedades como unidade, equilíbrio, harmonia, proporção, perfeição, esplendor, etc.

Esta oscilação da beleza entre a categoria, o conceito e a intuição é menos uma simples aporia do que um sintoma da sua natureza alotrópica. Se é certo que existem, historicamente, concepções objectivas e concepções subjectivas da beleza, com inúmeras nuances e divergências, isso não demonstra o seu carácter aporético, mas tão-só a sua natureza alotrópica, que deve ser entendida positivamente como característica definidora. $\mathrm{O}$ belo, tal como o Homem em Michel Foucault, pode pois ser pensado como um alótropo empírico-transcendental, de modo que as condições do seu conhecimento nos são dadas pelos seus próprios conteúdos empíricos ${ }^{48}$. A alotropia é uma propriedade particular de alguns elementos químicos e vocábulos linguísticos que lhes permite apresentarem-se sob diferentes formas e estados, atravessando divergências e mutações estruturais. Mutatis mutandis, esta propriedade, que também se verifica na lógica dos conceitos, explica a pluralidade teórica do belo e a correspondente falta de univocidade semântica. Uma propriedade afinal tropológica, e portanto retórica, que está na origem do drama conceptual que é o belo em toda a sua evolução e que faz dele, como de nenhum outro, a síntese esplendorosa da própria alotropia que é o Homem. Eis o drama da beleza a que a poesia de Sophia dá voz peculiar,

48. Cf. Michel Foucault, Les Mots et les Choses, Paris: Gallimard, 1966, p. 329. A ideia do Homem como "un étrange doublet empirico-transcendantal, puisque c'est un être tel qu'on prendra connaissance en lui de ce qui rend possible toute connaissance", acaba por se perder na tradução portuguesa de António Ramos Rosa, prefaciada por Eduardo Lourenço e Vergílio Ferreira, uma vez que o termo "doublet", que significa não exactamente "duplo" mas "alótropo", foi traduzido por "par": "O homem, na analítica da finitude, é um estranho par empírico-transcendental, pois é um ser tal que nele se tomará conhecimento do que torna possível todo o conhecimento" (Michel Foucault, As Palavras e as Coisas, Lisboa: Portugália, [1968], 414.) 
saindo fora dos limites do belo para se reencontrar com ele em toda a sua plenitude.

\section{Referências}

Baldine Saint Girons, Fiat Lux: Une Philosophie du Sublime, Paris: Quai Voltaire, 1993.

Charles Clair, Le Beau et les Beaux-Arts, Paris: Librairie H. Oudin, 1882.

Edmund Burke, A Philosophical Enquiry into the Origin of Our Ideas of the Sublime and Beautiful, Nova lorque: Oxford University Press, 1998.

Étienne Souriau, Les Catégories Esthétiques, Paris: Centre de Documentation Universitaire, 1966.

Friedrich Nietzsche, A Origem da Tragédia, Lisboa: Guimarães Editores, 1982.

Jacques Maritain, La Responsabilité de l'Artiste, Paris: Arthème Fayard, 1961.

Jorge de Sena, Prefácio a Poesia-I, Lisboa: Livraria Morais, 1961.

Luc Ferry, Le Sens du Beau: Aux Origines de la Culture Contemporaine, Paris: Librairie Générale Française, 2002.

Michel Foucault, Les Mots et les Choses, Paris: Gallimard, 1966

Platão, Fedro, Lisboa: Guimarães Editores, 1981.

Robert Blanché, Des Catégories Esthétiques, Paris: Vrin, 1979.

Sophia de Mello Breyner Andresen, O Nu na Antiguidade Clássica, Lisboa: Portugália, 1975.

Sophia de Mello Breyner Andresen, Obra Poética (3 vols), Lisboa: Caminho, 1991.

Teilhard de Chardin, O Fenómeno Humano, Apelação: Paulus, 1998 